\title{
GEOLOGIA DA EXTREMIDADE SUDOESTE DA SERRA DOURADA (GOIÁS, BRASIL)
}

\author{
JOSÉ CARUSO MORESCO DANNI*, MARCEL AUGUSTE DARDENNE*, \\ REINHARDT A. FUCK* e MARCELO JOSÉ RIBEIRO*
}

\begin{abstract}
Geologic mapping carried out in the Mossâmedes-Sanclerlândia - Córrego do Ouro region, State of Goiás, lead to the separation of the following geologic units in the southwestern part of the Serra Dourada:

The Basal Complex of Goiás occurs in the north of the area, comprising cataclastic muscovite-granite-gneiss and migmatitic biotite-gneiss.

The Araxá Group appears south of the ridge, and includes cordierite-hornblende-gneiss, garnet-biotite-muscovite gneiss, amphibolite, garnet-muscovite-schist, calcitic muscovite-biotite-schist and minor quartzite, marble and amphibole-schist. The sequence was intruded by two gabbro-norite-ultramaphite bodies, which are possibly chronologically related to a layer of greenschist unconformably overlying the Basal Complex in the North.

The Upper Precambrian Canastra Group is the youngest unit of the region. It rests unconformably over the Basal Complex and the greenschist, whereas towards the South it is separated through and inverse fault from the Araxá Group. The group is composed of tourmaline-chlorite-schist, muscovitic quartzite with numerous intraformational conglomerate lenses in the upper part, quartz-schist and phyllite.
\end{abstract}

INTRODUÇÃo No presente trabalho é apresentada uma síntese preliminar da geologia do segmento sudoeste da Serra Dourada, Estado de Goiás. A área estudada está compreendida entre as coordenadas $16^{\circ}$ e $16^{\circ} 17^{\prime}$ de latitude sul, e $50^{\circ}$ e $50^{\circ} 33^{\prime}$ de longitude oeste de Greenwich, apresentando uma extensão de aproximadamente $1800 \mathrm{~km}^{2}$. Localiza-se a noroeste de Goiânia, capital do Estado de Goiás, da qual dista cerca de $120 \mathrm{~km}$ pela rodovia pavimentada BR-73 (Fig. 1).

Os trabalhos de campo foram realizados em julho-agosto de 1969 por uma equipe de professores e alunos do Departamento de Geociências da Universidade de Brasília. O objetivo dos trabalhos foi o treinamento dos então formandos em Geologia em problemas de mapeamento geológico regional, ao mesmo tempo que se perseguia o conhecimento geológico pormenorizado de uma parte do Planalto Central. A região foi dividida em seis áreas, e cada uma mapeada por uma dupla de graduandos sob a supervisão de um professor.

Com base nos dados obtidos no terreno, complementados com estudos de laboratório, cada dupla elaborou o mapa geológico de sua área (escala $1: 60000$ ), acompanhado do respectivo relatório. Objetivando divulgar os resultados obtidos, os autores da presente contribuição revisaram e compilaram os referidos trabalhos, tendo, inclusive, voltado à área, em 1971, para o esclarecimento de aspectos controvertidos da estratigrafia e tectônica regionais.

Trapalnos anteriores A região da Serra Dourada, ao sul de Goiás, antiga capital do Estado de Goiás, mereceu diversas referências na bibliografia geológica brasileira Percorrida por Castelnau e Hussak (Oliveira e Leonardos, 1943), foi descrita mais tarde por Leinz e Leonardos (1936), que consideraram algonquiana inferior a idade dos quartzitos

*Departamento de Geociências, Universidade de Brasília 

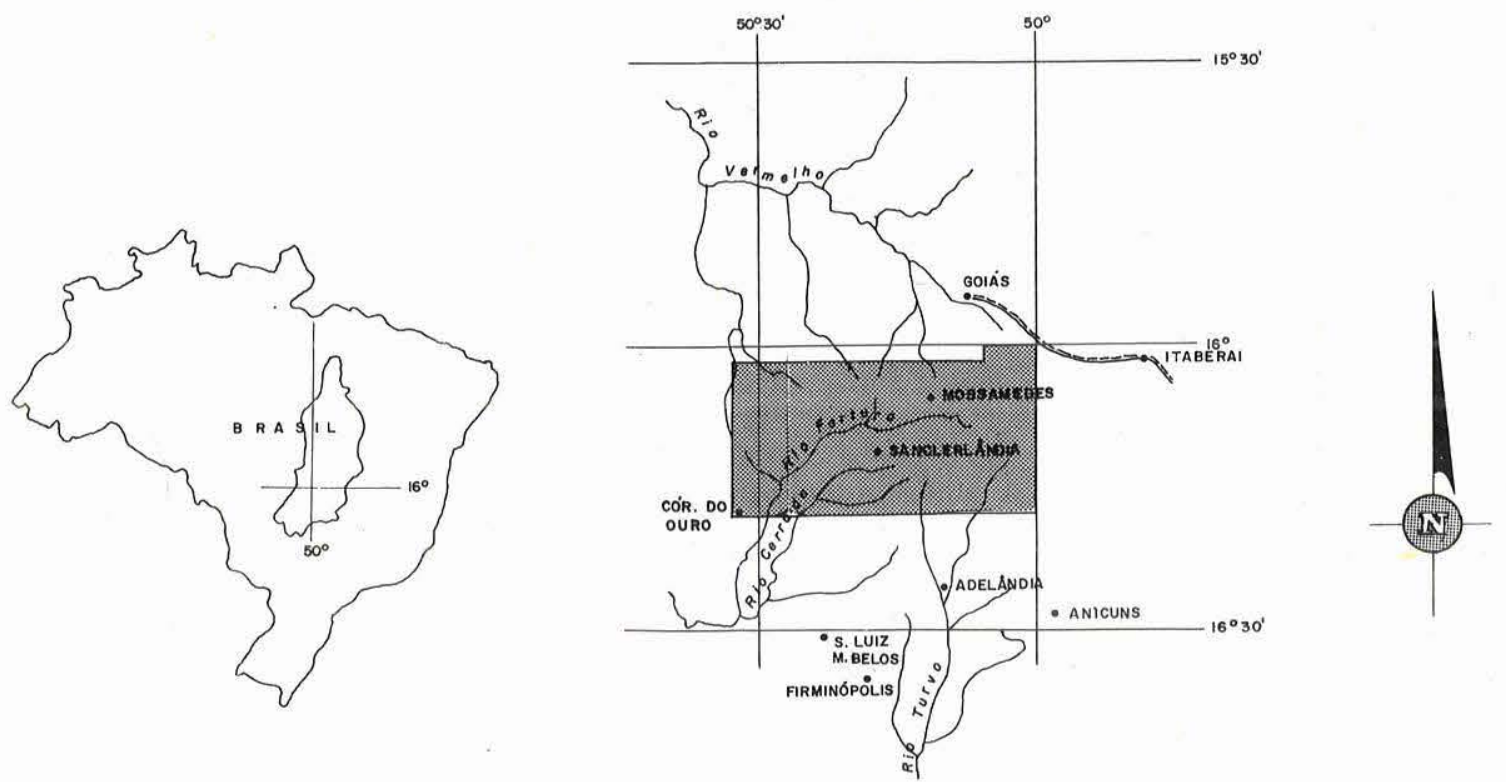

Figura 1 - Mapa de localização

micáceos (itacolomitos) e outros xistos cristalinos que sustentam a Serra Dourada, incluindo-os na Série Minas. O granito encontrado entre Goiás e a serra foi atribuído ao Arqueano.

Leonardos (1938), referindo-se ao granito de granulação média, muito quartzoso, que encontrou nos arredores de Goiás, considerou-o arqueozóico. Os sobrepostos quartzitos sericíticos da Serra Dourada foram comparados à Série Minas. O mesmo autor mencionou a ocorrência de calcário sacaróide, claro, com veias cinzentas, e clorita xistos com actinolita e pirita na Fazenda Conceição, próximo de Mossâmedes. Referiu também a presença de ouro, diamante e abundante rutilo nas aluviões da região, principalmente no Ribeirão Conceição.

Erichsen e Miranda (1939) fizeram observações geológicas na área, atribuindo os filitos quartzosos, quartzitos itacolomíticos e mica xistos de Goiás e Mossâmedes ao Algonquiano, comparando-os à Série Minas, ao mesmo tempo que classificaram o gnaisse granítico de Goiás no Arqueano.

Oliveira e Leonardos (1943), sintetizando os conhecimentos geológicos da região, presumiram ser laurentiana a idade do granito quartzoso encontrado nos arredores de Goiás, e, igualmente, consideraram pertencentes à Série Minas os quartzitos que sustentam a Serra Dourada, bem como os filitos, talco xistos e anfibolita xistos que ocorrem na cidade de Goiás e na região de Mossâmedes.

Segundo Andrade Ramos (1958), a Serra Dourada é um hogback quartzítico de direção $\mathrm{S} 65^{\circ} \mathrm{O}$. Os quartzitos micáceos tipo itacolomito que a constituem e os xistos finos associados são, segundo esse autor, correlacionáveis à Série Minas ou à Série Canastra. No embasamento dos quartzitos, registrou a presença de granito branco, pegmatítico, com grandes cristais de mica, e gnaisses quartzosos verticais, de xistosidade $\mathrm{N} 30^{\circ} \mathrm{O}$. $\mathrm{O}$ mesmo autor referiu também que $15 \mathrm{~km}$ ao norte de Mossâmedes afloram os mica xistos da Série Araxá, com leitos intercalados de quartzitos, que se estendem até São Luiz de Montes Belos, associados a biotita gnaisse e quartzitos, com mergulhos predominantes para sul. 
Almeida (1967) distinguiu quatro ciclos tecto-orogênicos na região central de Goiás. Os dois mais antigos, compreendendo rochas gnáissicas, migmatitos e metabasitos, com mica xistos, metaconglomerados e quartzitos subordinados, além de granitos abundantes, foram denominados de Complexo Basal por esse autor. O terceiro ciclo corresponde a uma seqüência metassedimentar de ambiente eugeossiclinal, recobrindo discordantemente o Complexo Basal. Trata-se do Grupo Araxá (Barbosa, 1955), constituído de biotita xistos e quartzitos, paragnaisses, mármores, anfibolitos e migmatitos. Esse ciclo teve magmatismo básico e ultrabásico como manifestação precoce, representado por dupla faixa de gabros, piroxenitos e peridotitos serpentinizados, de idade próxima de 1100 m.a.

Seguindo o metamorfismo e dobramento do grupo, realizaram-se intrusões de rochas granitóides e pegmatitos, cuja idade se aproxima de 850-900 m.a. O ciclo mais jovem corresponde à evolução do miogeossinclíneo Brasília, representado, segundo Almeida (1967), pelos grupos Canastra e Bambuí, no primeiro dos quais incluiu o quartzito que suporta a Serra Dourada.

Algumas das datações K/Ar apresentadas por Hasui e Almeida (1970) referem-se a rochas coletadas na região objeto da presente contribuição: (a) amostra SPK 1 114-GO-223, anfibolito atribuído ao Complexo Basal, coletado no ribeirão da Fartura, $7 \mathrm{~km}$ de Perdizes para Sanclerlândia, com $604 \pm 30$ m.a.; amostra SPK 1 154-GO-211, muscovita xisto procedente do pé da Serra Dourada, ao norte de Mossâmedes, com $585 \pm 29$ m.a., considerado pertencente ao Grupo Araxá; SPK 1 158-GO-213, filito obtido no alto da Serra Dourada, ao norte de Mossâmedes, com $541 \pm 27$ m.a., tido como integrante do Grupo Canastra; SPK 1 180-GO-201, muscovita gnaisse proveniente do Rio Vermelho, 3,5 km de Goiás para Goiânia, com $1199 \pm 60$ m.a., julgado pertencer ao Complexo Basal. $\mathrm{Na}$ interpretação dos autores mencionados, estariam, portanto, presentes na área rochas do Complexo Basal Goiano, e rochas pertencentes às estruturas Araxaídes e Brasilides, geradas respectivamente nos ciclos Uruaçuano e Brasiliano.

Aspectos geomorfológicos A região estudada está compreendida no Planalto Central Brasileiro, que se caracteriza regionalmente por um relevo suavemente ondulado, e que, ocasionalmente, tem a sua monotonia interrompida por cristas e espigões mantidos por algumas rochas menos afetadas pelo intemperismo.

Morfologicamente, a área se caracteriza pela presença dominadora da Serra Dourada, extenso hogback de rumo oés-sudoeste-lés-nordeste, sustentado por algumas camadas de quartzito, com o fronte alcantilado e abrupto voltado para o norte. $\mathrm{O}$ reverso, acompanhando o mergulho das camadas, inclina-se com $15-20^{\circ}$ para sul, e nele se distingue uma sucessão de hogbacks menos salientes, suportados por xistos, até morrer no típico relevo ondulado de xistos e gnaisses. A altitude da serra oscila entre 800 e $850 \mathrm{~m}$, num contraste marcante com as altitudes de $510 \mathrm{~m}$ em Goiás, ao norte, e de $600 \mathrm{~m}$ em Mossâmedes, ao sul. Na porção mais elevada da serra, ao norte de Mossâmedes, observa-se um pequeno platô horizontalizado, sustentado por crosta de laterita concrescionária espessa, de 1-2 m, e que testemunha uma antiga superficie de aplainamento cortando o topo da Serra Dourada.

Diante do front escarpado da serra, o relevo esculpido nos gnaisses é ondulado e coberto por denso cerrado, que dá lugar a matas condicionadas aos solos mais férteis das extensas ocorrências de xistos magnesianos, que se caracterizam também por uma topografia mais acidentada, com vales estreitos de vertentes íngremes.

Ac sul da serra, os terrenos ondulados são inter rompidos por algumas cristas de quartzitos e pelas serras de São João e Mangabal. A primeira sustenta-se em cordierita-hornblenda gnaisses e a última em granada-muscovita xistos e quartzitos, cujo rumo 
lés-nordeste-oés-sudoeste inicial inflete bruscamente para sul, prolongando-se além da cidade de São Luiz de Montes Belos.

A porção da área situada ao sul desses acidentes apresenta características morfológicas diversas das anteriores, fato que se deve à presença de rochas básicas e ultrabásicas. Mais suscetíveis à decomposição, deram margem a uma topografia caracterizada por amplas e arredondadas colinas, com solos espessos e férteis, cobertas de vegetação mais abundante e vigorosa, e intensivamente aproveitadas para a agricultura e pastagens. Finalmente, a porção leste da área é plana, suportada por laterita, e coberta de cerrado denso.

A região é drenada sobretudo por tributários da bacia do Araguaia. Ao norte da serra, correm os rios Indio e Vermelho, e, ao sul, aparecem os ribeirões Conceição e Fartura. A região leste é drenada por formadores do Rio Uru, afluente do Rio das Almas, da bacia do Tocantins.

Estratigrafia COLUNA ESTRATIGRÁFICA A coluna estratigráfica proposta para a região que se estende ao sul da cidade de Goiás compreende, da base para o topo, a seqüência litológica enumerada a seguir.

1. O complexo "granito-gnáissico", cuja área de ocorrência é restrita ao norte da Serra Dourada. Caracteriza-se por "granito-gnaisses" geralmente muscovíticos, brancos, localmente pegmatóides. Somente na parte ocidental da área, ocorrem fácies biotíticas e migmatíticas. Neles se encontram intercalações de muscovita-quartzo xistos grosseiros e algumas ocorrências de metabasitos e clorita-talco xistos intensamente dobrados que representam uma primeira geração de intrusões básicas na região.

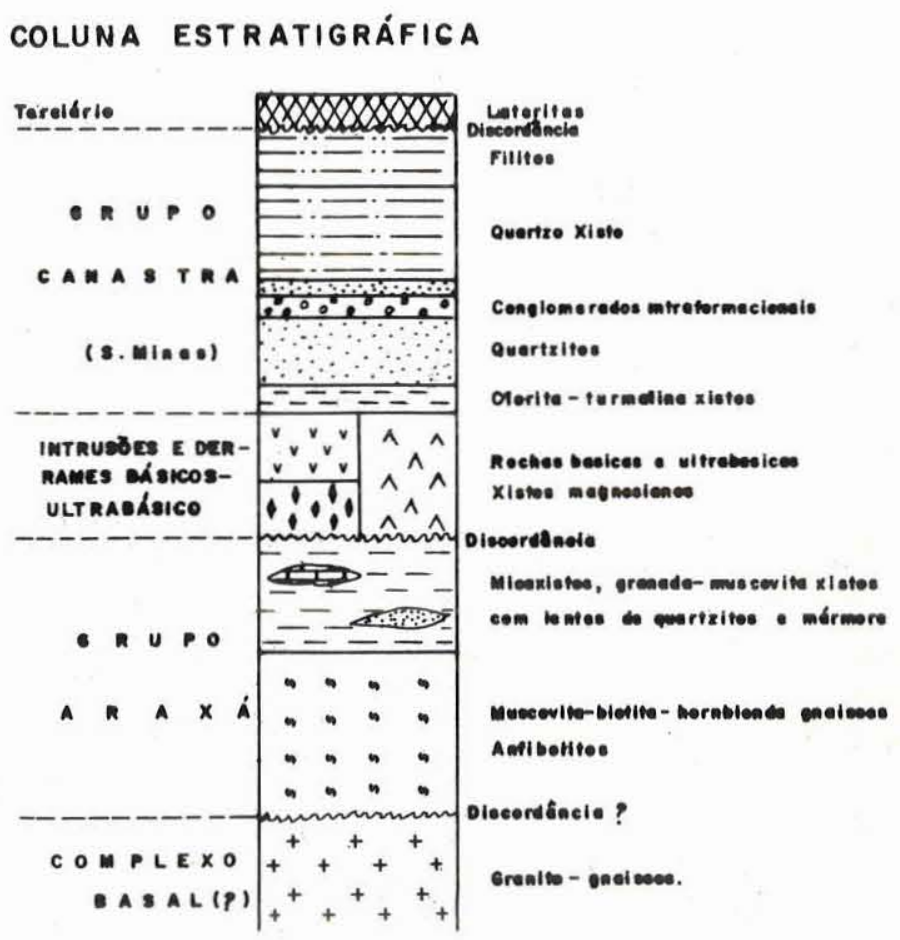

Figura 2 - Coluna estratigráfica 

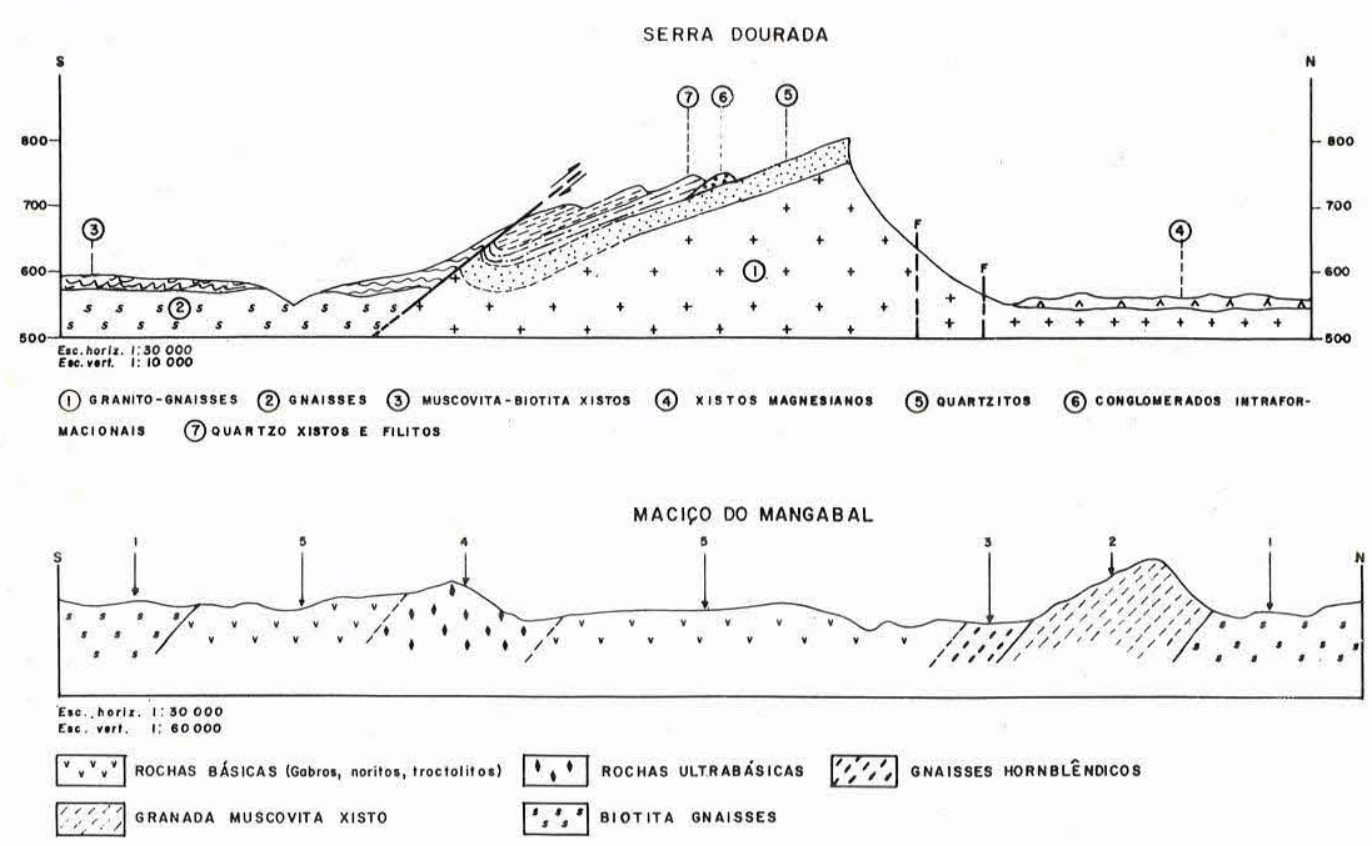

Figura 3 - Cortes geológicos da Serra Dourada e Maciço do Mangabal

2. Os gnaisses típicos, finamente bandados, aparecem exclusivamente ao sul da Serra Dourada. Por essa razão, não foi possível estabelecer as suas relações com a unidade precedentemente descrita. Petrográficamente, podem ser separados em:

muscovita-biotita gnaisses;

granada-biotita-muscovita gnaisses;

hornblenda-biotita gnaisses;

cordierita-hornblenda gnaisses.

Contêm lentes de anfibolitos, sobretudo epídoto anfibolitos e granada-epídoto anfibolitos.

3. Os mica xistos sobrepõem-se concordante e transicionalmente a esses gnaisses. Distinguem-se principalmente biotita xistos calcíferos, granada-biotita-muscovita xistos, granada-muscovita xistos e estaurolita-granada-muscovita xistos.

Bancos de quartzitos intercalados nos mica xistos, chegam a constituir lentes mapeáveis na escala considerada. Algumas vezes, os quartzitos são hematíticos. No topo da seqüência, localiza-se uma lente de mármore com nítida estratificação sublinhada por bandas de cor cinza e branco.

4. Após, instalou-se o magmatismo básico e ultrabásico que se manifestou sob duas formas bem distintas, atualmente representados conforme expomos a seguir

a) Talco-clorita xistos e metabasitos que provavelmente correspondam a derrames de lavas, diques e pequenos corpos intrusivos metamorfizados. Ocorrem sobretudo ao norte da Serra Dourada, onde talco-clorita xistos cobrem extensas superfícies, sobrepondo-se diretamente ao complexo "granito-gnáissico" que aparece nos vales. A sua espessura máxima é da ordem de 15 a $20 \mathrm{~m}$.

A correlação desses xistos com lavas básicas é baseada na presença de relictos de olivina e piroxênio. A esses xistos e sobretudo aos pequenos corpos ultrabásicos talcificados são ligadas as principais ocorrências de talco da região. 
b) Corpos intrusivos de rochas básicas e ultrabásicas que afloram ao sul das serras de São João e Mangabal. Trata-se de complexos diferenciados, alinhados no rumo leste-oeste, intrusivos em gnaisses e mica xistos. São constituídos sobretudo de gabros, noritos, troctolitos, piroxenitos e peridotitos.

5. Um novo ciclo sedimentar iniciou-se com uma camada descontínua e espessa, de $5 \mathrm{~m}$ de turmalina-clorita xisto, que assenta discordantemente sobre o complexo "granito-gnáissico" do norte da área.

6. Acima dessa fina camada e, muitas vezes, em contato direto com o complexo de base, ocorrem os quartzitos maciços, geralmente muscovíticos, que constituem o hogback da Serra Dourada. A espessura dessa unidade, que se afina para oeste, atinge 40 a $50 \mathrm{~m}$.

7. Nos últimos metros do pacote quartzítico, aparece um nível conglomerático descontínuo, mas constante quanto a sua posição estratigráfica. As lentes conglomeráticas, que podem atingir $15 \mathrm{~m}$ de espessura e várias centenas de metros em comprimento, são constituídas por seixos bem arredondados, estirados em elipsóides alongados devido aos esforços tectônicos. A matriz arenosa pode ser localmente rica em muscovita.

8. Aos conglomerados superpõe-se um banco de quartzito de 2 a $3 \mathrm{~m}$ de espessura com característica estratificação cruzada. Essa camada marca o início de uma alternância de bancos de quartzitos, onde as marcas de ondas são freqüentes, com quartzo xistos localmente ricos em clorita, muscovita e turmalina. A seqüência apresenta uma espessura estimada em $250 \mathrm{~m}$. A ela se sobrepõe uma unidade onde predominam os filitos sericíticos e cloritosos com alguns níveis grafitosos na parte superior.

Todo o conjunto se adelgaça no sentido oeste, desaparecendo na extremidade ocidental da área.

9. As lateritas estabeleceram-se sobre a superficie de aplainamento realizada nos tempos terciários.

10. Alguns solos poucos espessos, geralmente arenosos, aluviões e coluviões, podem ser considerados como os últimos produtos sedimentares de um passado recente.

Discussão da coluna estratigráfica A coluna proposta constitui uma interpretação global da área mapeada calcada nas inter-relações observadas das diversas litologias aflorantes.

Caminhando-se de norte para sul, perpendicularmente à direção da Serra Dourada, a primeira impressão é de que os quartzitos maciços, assim como a seqüência de quartzo xistos sobrepostos são estratigraficamente inferiores aos mica xistos que ocorrem ao sul. No decorrer do mapeamento, essa interpretação mostrou-se, entretanto, insustentável, tendo-se em vista os fatos a seguir enumerados.

1. A descoberta, no topo dos quartzo-xistos, de uma seqüência de filitos sericíticos e cloritosos, que estão sotopostos aos mica xistos granadíferos, intensamente microdobrados com planos axiais mergulhando aproximadamente $20^{\circ}$ para sudoeste. Essa diferença no grau de metamorfismo entre as duas unidades levou a considerar o contato como tectônico.

2. Na secção realizada a partir da Fazenda Serrinha (Fig. 2) em sentido norte e subindo o reverso da Serra Dourada, encontra-se, no Córrego Serrinha (cota 575 m), granada-muscovita-biotita xistos com coordenadas $\mathrm{N} 75^{\circ} \mathrm{W}, 20^{\circ} \mathrm{SW}$, enquanto os filitos aparecem ainda nas cotas 675 e $695 \mathrm{~m}$ com coordenadas sensivelmente iguais.

3. Ao sul da Serra Dourada, os biotita gnaisses ocorrem logo abaixo dos mica xistos. Assim, todo o espesso pacote de quartzitos e quartzo xistos desapareceria em algumas centenas de metros.

4. Uma passagem transicional e progressiva dos mica xistos aos gnaisses foi observada em várias partes da área. 
5. O desaparecimento da seqüência de quartzo xistos e filitos no sentido oeste e a marcante silicificação dos quartzitos, cavalgados pelos biotita xistos.

Por essas razões, foi inferido um contato tectônico (falha inversa) entre a seqüência dos quartzo xistos encimados por filitos e os biotita xistos calcíferos.

Correlações É apresentada uma tentativa de estabelecer as possíveis correlações entre essas unidades e as conhecidas no centro-oeste e centro-sul brasileiro.

Os granito gnaisses de Goiás, que constituem a região norte da área estudada, provavelmente pertençam ao Complexo Basal (Almeida, 1967 e 1970).

Os gnaisses à muscovita, biotita e granada; os mica xistos granadíferos com cianita e estaurolita, que ocorrem no sul da área, são correlacionáveis à Série Araxá (Barbosa, 1955; Almeida, 1967; Barbosa et al., 1970), dado que apresentam identidade petrográfica (composição e fácies metamórficas), estruturológicas e de associação litológica, com a referida série.

As intrusões básico-ultrabásicas do sul da área mostram relações estratigráficas (intrusiva nos gnaisses e xistos precedentes) e associações petrográficas (gabros, noritos, troctolitos, piroxenitos e peridotitos) semelhantes às dos maciços de Niquelândia, Barro Alto e Canabrava (Pecora e Barbosa, 1944; Barbosa et al., 1970; Figueiredo et al., 1970; Milewski et al., 1970; Lindenmayer, Z. G. e D. H., 1971).

A seqüência metassedimentar da Serra Dourada apresenta características afins com os grupos Canastra e Araí. Litologicamente esses grupos começam por espessos pacotes quartzíticos que contêm lentes de conglomerados encimados por filitos sericíticos, quartzosos e grafitosos. Encontram-se sobrepostos discordantemente a gnaisses e xistos Araxá (Barbosa, 1955; Almeida, 1967; Barbosa et al., 1970).

Diversos autores que percorreram a presente região (Leinz e Leonardos, 1936; Leonardos, 1938; Erichsen e Miranda, 1939; Oliveira e Leonardos, 1943; Andrade Ramos, 1958) consideraram a seqüência da Serra Dourada como equivalente à Série Minas.

Geologia geral e petrografia O COMPLEXO GNÁISSICO DE GOIÁS Muscovita-microclínio gnaisses cataclásticos Esses gnaisses ocorrem imediatamente ao norte da Serra Dourada e encontram-se bem expostos nas imediações da cidade de Goiás. Afloram em morros arredondados, às vezes muito salientes ou em áreas arrasadas, onde se desenvolve um solo branco quartzo-caulínico, produto da decomposição de seus feldspatos.

Nos afloramentos apresentam uma orientação difusa, pouco conspícua na amostra de mão, marcada pela orientação das palhetas de muscovita e dos cristais de microclínio.

Em lâmina, o microclínio apresenta-se invariavelmente fissurado, com formas arredondadas ou angulares por efeitos cataclásticos, associado ao plagioclásio (albita-oliglásio) com geminações deformadas. A muscovita ocorre em palhetas milimétricas dispostas entre esses cristais ou nas fieiras ou lentículas cataclásticas de quartzo, feldspato e epídoto. A biotita é rara.

Essas feições sugerem tratar-se de antigo núcleo granítico afetado por um metamorfismo dinâmico generalizadio. Localmente, derdo ao maior desenvolvimenten da cataclase, ocorrem feições de rochas fiaser.

Nessa região, no lado mais ocidental da área, ocorrem gnaisses a muscovita e biotita, com nítida estrutura bandada e localmente com fácies migmáticas, caracterizadas pela presença de vênulas e filões quartzo-feldspáticos, de aspecto granítico ou pegmatítico.

Muscovita xistos com olhos de quartzo Esses xistos ocorrem localmente intercalados ou sobrepostos aos gnaisses anteriores e, às vezes, imediatamente abaixo dos quartzitos da 
Serra Dourada. A sua posição estratigráfica não está totalmente esclarecida. Provisoriamente consideramos como pertencentes ao Complexo Gnáissico de Goiás. Apresentam uma xistosidade bem desenvolvida, conferida pelo paralelismo das lâminas interdigitadas de muscovita com níveis quartzosos. A feição marcante é a presença de olhos milimétricos de quartzo.

O COMPLEXO GNÁISSICO DO SUL Cordierita-hornblenda gnaisses A Serra de São João, no sudeste da área, é constituída de gnaisses leucocráticos de granulação média, cor rósea e fracamente bandados. Trata-se de gnaisses ricos em oligoclásio e microclínio, contendo, além de quartzo, hornblenda e biotita; e a cordierita detectada no microscópio.

No sopé da serra, graduam para hornblenda gnaisses portadores de biotita e muscovita.

Muscovita-biotita gnaisses Esses gnaisses constituem a litologia dominante de toda região meridional da área. Encontram-se concordantemente sobrepostos aos mica xistos granadíferos, ocorrendo no seio destes em janelas ou nos talvegues dos principais cursos dágua.

Petrograficamente, apresentam-se regularmente bandados onde faixas milimétricas ou centimétricas quartzo-feldspáticas intercalam-se com outras micáceas. A granada com freqüência está presente.

Microscopicamente constam de quartzo, seguidamente ondulante, ortoclásio ou microclínio micropertíticos, parcialmente muscovitizados, oligoclásio com inclusões de epídoto, biotita às vezes cloritizada, muscovita e epídoto. A textura é granoblástica.

Feições cataclásticas são muito freqüentes e, em alguns locais, adquirem fácies xistosas por efeito de filonitização.

Granada epidoto anfibolitos Associados aos gnaisses ora descritos ocorrem lentes métricas ou hectométricas de anfibolitos.

Trata-se de rochas verde escuras, fortemente lineadas, compostas basicamente de hornblenda, plagioclásio, epídoto, granada e quartzo. Ao micróscopio, identifica-se ainda a biotita derivada da horblenda, zoisita, titanita, muscovita, ortoclásio e opacos em proporções variáveis. A saussuritização do plagioclásio e a cloritização da hornblenda e biotita são feições generalizadas.

OS MICA XISTOS E ROCHAS ASSOCIADAS Granada-muscovita xistos É o tipo petrográfico mais comum entre os xistos da região sul da área. Seus componentes são facilmente identificados, posto que as lamelas de muscovița atingem até $1 \mathrm{~cm}$, e os porfiroblastos idiomórficos de granada chegam até $2 \mathrm{~cm}$. Nas superficies dos afloramentos, mormente quando intemperizados, os cristais de granada tornam-se salientes e a rocha toma um aspecto noduloso. A xistosidade é sempre grosseira e corrugada.

Menos comuns que os xistos anteriores, são ainda encontrados biotita-muscovita xistos ou biotita xistos, granadíferos ou não.

A esses xistos, associam-se, às vezes, a estaurolita, em prismas milimétricos, geralmente muscovitizada; o rutílio em cristais de até $3 \mathrm{~cm}$, agulhas de ferroactinolita e epídoto, que constituem eventuais acessórios. Intercalados nos xistos, freqüentemente ocorrem camadas centimétricas a métricas de quartzitos e xistos quartzosos. Os últimos, às vezes, contêm prismas centimétricos de cianita e granada (Fotomicrografial).

A transição para os gnaisses é contínua e se reflete pela aparição de fácies facóides constituídas de quartzo, plagioclásio e principalmente microclínio.

Microscopicamente, sobressaem-se os porfiroblastos de granada parcialmente cloritizada, fissurada, seccionando a xistosidade ou rotacionada. A muscovita e biotita dis- 


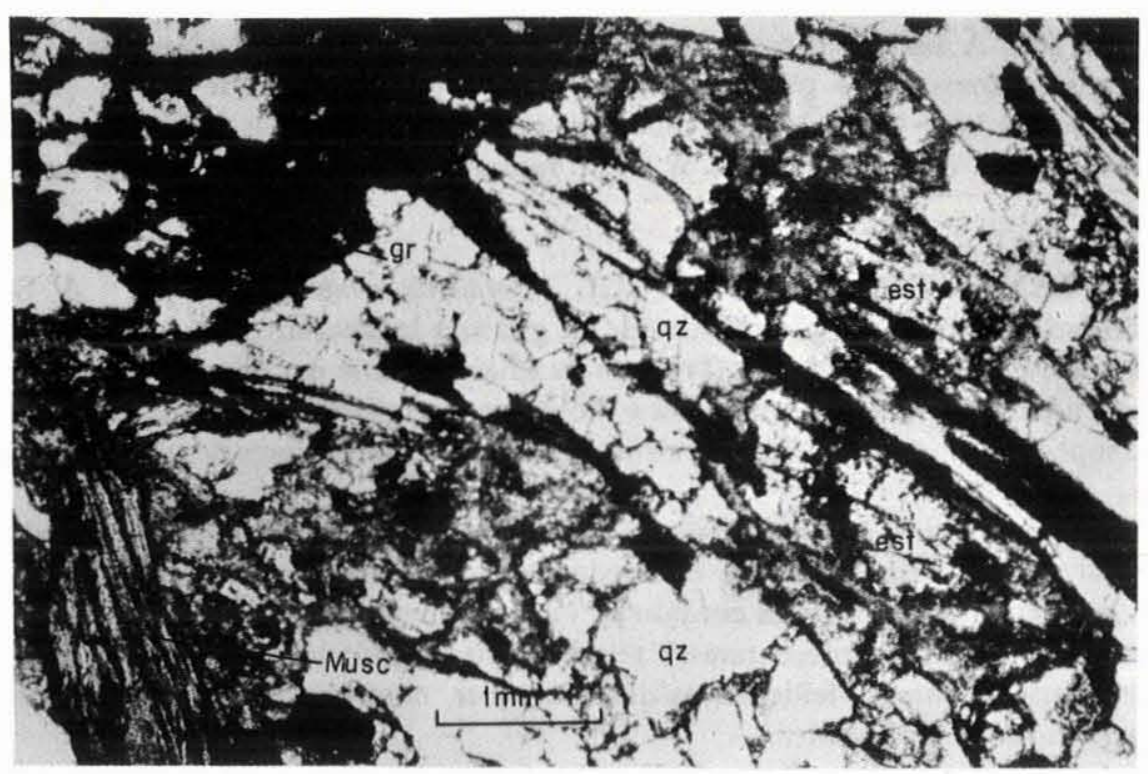

Fotomicrografia 1 - Estaurolita-granada-muscovita xistos. No canto superior esquerdo, parte de um porfiroblasto de granada. No centro, relictos de estaurolita muscovitizada. LP, $25 \mathrm{X}$

tribuem-se em níveis microdobrados justapostos a níveis quartzosos e feldspáticos (oligoclásio, microclínio/ortoclásio).

Dentro dos xistos, ocorrem camadas de anfibólio xistos, ricos em hornblenda, calcita e granada, a que se somam muscovita, biotita, quartzo, epídoto e oligoclásio.

Quartzitos e quartzitos hematíticos Compreendem algumas lentes quartzíticas intercaladas nos biotita-muscovita xistos que se encontram individualizadas no mapa. Apresentam-se em bancos decimétricos, muito duros, com brilho vítreo nas fraturas. Suas cores variam entre o branco e o cinza em função das quantidades de quartzo, muscovita, biotita e hematita.

Alguns níveis são especialmente ricos em hematita, que ocorre tanto disseminada como faixas compactas segundo o acamamento.

Mármore Corresponde a uma lente de cerca de $800 \mathrm{~m}$ de comprimento que ocorre no seio dos mica xistos. Apresenta uma estrutura listrada pela alternância regular de leitos milimétricos cinza-escuros e brancos. Microscopicamente, consta de um mosaico granular de calcita.

Foi observada a ocorrência restrita de xistos talcosos nas bordas dessa lente.

Biotita xistos calcíferos No flanco sul da Serra Dourada, desenvolvendo-se por toda sua extensão, ocorre uma faixa de cerca de $600 \mathrm{~m}$ de largura de biotita xisto calcífero, sobreposto por falha inversa aos filitos e quartzo xistos.

No campo, são facilmente visualizados, dado que formam morros arredondados, uniformes, com uma vegetação de matos ou campos limpos devido ao desmatamento.

Apresentam cor cinza-escura a preta, uma fina xistosidade de cristalização, geralmente sanfonada e obliterada por uma xistosidade secundária de fluxo (xistosidade "S"). 
A biotita ocorre em palhetas diminutas associada à muscovita. O quartzo forma níveis ou lentículas milimétricas de segregação. A calcita é prontamente evidenciada pela reação com ácido.

No microscópio, observam-se, além desses minerais, epídoto, às vezes muito abundante, calcita e albita associadas em níveis granulares. A granada é comum e sempre submilimétrica. Fortes efeitos de cisalhamento nos níveis granulares são sempre 'observados (Fotomicrografia 2).

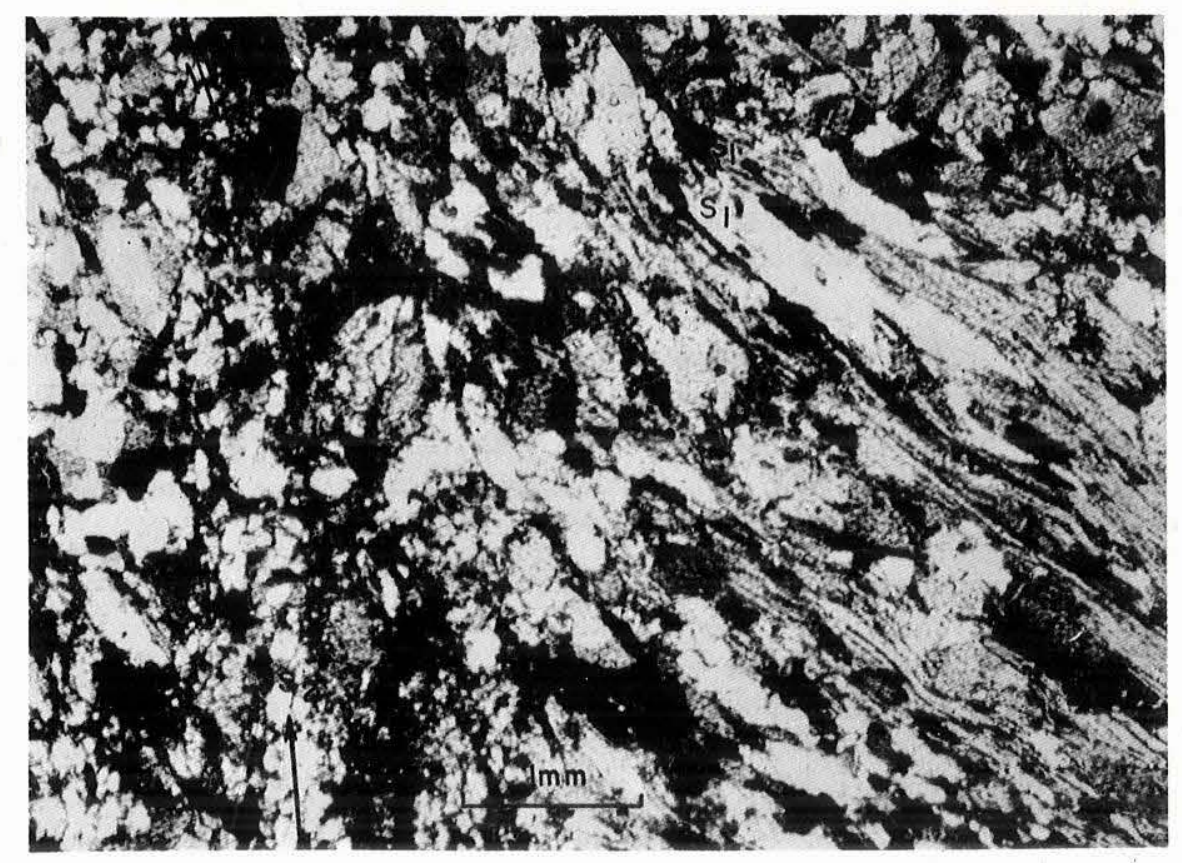

Fotomicrografia 2 - Muscovita xisto calcífero mostrando a xistosidade primária $\left(S_{1}\right)$, seccionada por xistosidade secundária de fluxo $\left(S_{2}\right)$. LP, $25 \times$

OS MACIÇOS BÁSICO-ULTRABÁSICOS Dois maciços básico-ultrabásicos ocorrem no extremo sul da área mapeada e encontram-se limitados parcial e respectivamente pelas serras do Mangabal e São João.

O corpo de Mangabal tem uma forma ovalada cujos eixos maiores medem cerca de $6 \times 4 \mathrm{~km}$ e é intrusivo nos muscovita-biotita gnaisses e muscovita-granada xistos formadores da serra homônima.

O outro maciço é alongado na direção leste-oeste e mede $20 \times 3 \mathrm{~km}$. É intrusivo em hornblenda-cordierita gnaisses e em biotita gnaisses.

Nas margens desses corpos ocorrem gnaisses hornblêndicos caracterizados pela presença de abundantes cristais centimétricos de hornblenda associada a andesina, quartzo, feldspato K, e epídoto. Essa litologia forma uma estreita faixa entre o corpo intrusivo e os gnaisses e é interpretada como resultante de endometamorfismo marginal dos maciços.

$\mathrm{Na}$ borda leste, o maciço do Mangabal está em contato com os gnaisses regionais através da falha existente ao longo do Rio Turvo. Nessa área e na borda sul, as relações entre as litologias estão mascaradas pela cobertura de espessos solos e densa vegetação. 
Ao longo de $600 \mathrm{~m}$, os gabros do maciço do Mangabal estão em contạto com os muscovita-granada xistos, que contêm níveis quartzosos ricos em granada e cianita.

O estudo petrográfico desses xistos revelou a presença de cloritóide em cristais idiomórficos arranjados em feixes e crescido sobre um fundo muscovítico.

A paragênese desses xistos pertence a fácies almandina anfibolito (zona da cianita) e encontra-se em desequilíbrio com a presença de cloritóide, possivelmente relacionado ao metamorfismo térmico do maciço (Winkler, 1967).

Esses fatos sugerem que a intrusão do maciço efetuou-se após o metamorfismo regional máximo e num nível térmico de fácies albita-epídoto hornfels (Winkler, 1967).

A ação intrusiva é ainda marcada pela ocorrência de falhas e fraturas que cortam radialmente as encaixantes.

O maciço do Mangabal apresenta uma zonalidade petrológica que consiste em um núcleo constituído de rochas ultrabásicas (peridotitos talcificados e serpentinizados; piroxenitos) envolvido por rochas básicas (gabro, norito, troctolito, etc.) (Fig. 2).

As rochas básicas Afloram em campos de matacões, nas quebras de relevo, imersos em solo laterítico vermelho, rico em magnetita.

Microscopicamente são rochas escuras, de grão médio a fino. Em fratura fresca, os feldspatos apresentam uma cor violácea (labradorita), e estão associados aos máficos (diopsídio, hiperstênio e ou olivina).

Petrograficamente constam dos tipos comentados a seguir.

a) Gabros e hiperstênio gabros. São compostos de diopsídio (variedade diálaga) e de labradorita em ripas sempre geminadas nas leis albita e albita-carlsbad. Subordinadamente contêm hiperstênio e hornblenda uralítica. Ocorrem ainda a pistacita, zoisita, titanita, apatita e opacos.

b) Noritos. Constituem um tipo petrográfico subordinado nos maciços. Caracterizam-se por um ortopiroxênio fortemente pleocróico $(\mathrm{Ng}=$ rosa e $\mathrm{Np}=$ castanho-azulado) e que contêm finas exsoluções de clinopiroxênio segundo as clivagens (010) (tipo Bushveld). Trata-se do hiperstênio. Associam-se o plagioclásio (labradorita), a hornblenda uralítica e a biotita secundária (Fotomicrografia 3).

c) Olivina noritos e troctolitos. Essas rochas graduam com as demais através da variação da razão olivina/hiperstênio. O plagioclásio usual é a labradorita, podendo, às vezes, chegar a bitownita.

A feição petrográfica marcante é o desenvolvimento generalizado de coroas de reação em torno das olivinas. As coroas podem ser simples, i.e. formadas exclusivamente de um envoltório de hiperstênio, ou múltiplas, quando desde o núcleo de olivina apresentam-se em faixas que se sucedem na seguinte ordem: hiperstênio, clinopiroxênio e anfibólio verde (hornblenda). Às vezes, associa-se uma quarta faixa representada pelo intercrescimento simpléctitico de anfibólio e feldspatos (Fotomicrografias 3 e 4).

Os minerais formadores das auréolas encontram-se em geral perpendicularmente crescidos à interface olivina-plagioclásio.

O aumento de volume causado pela formação das coroas através da reação olivina-plagioclásio, reflete-se no interior dos feldspatos circundantes pelo aparecimento de fissuras radiais.

Segundo o critério textural são classificados como coronitos. 


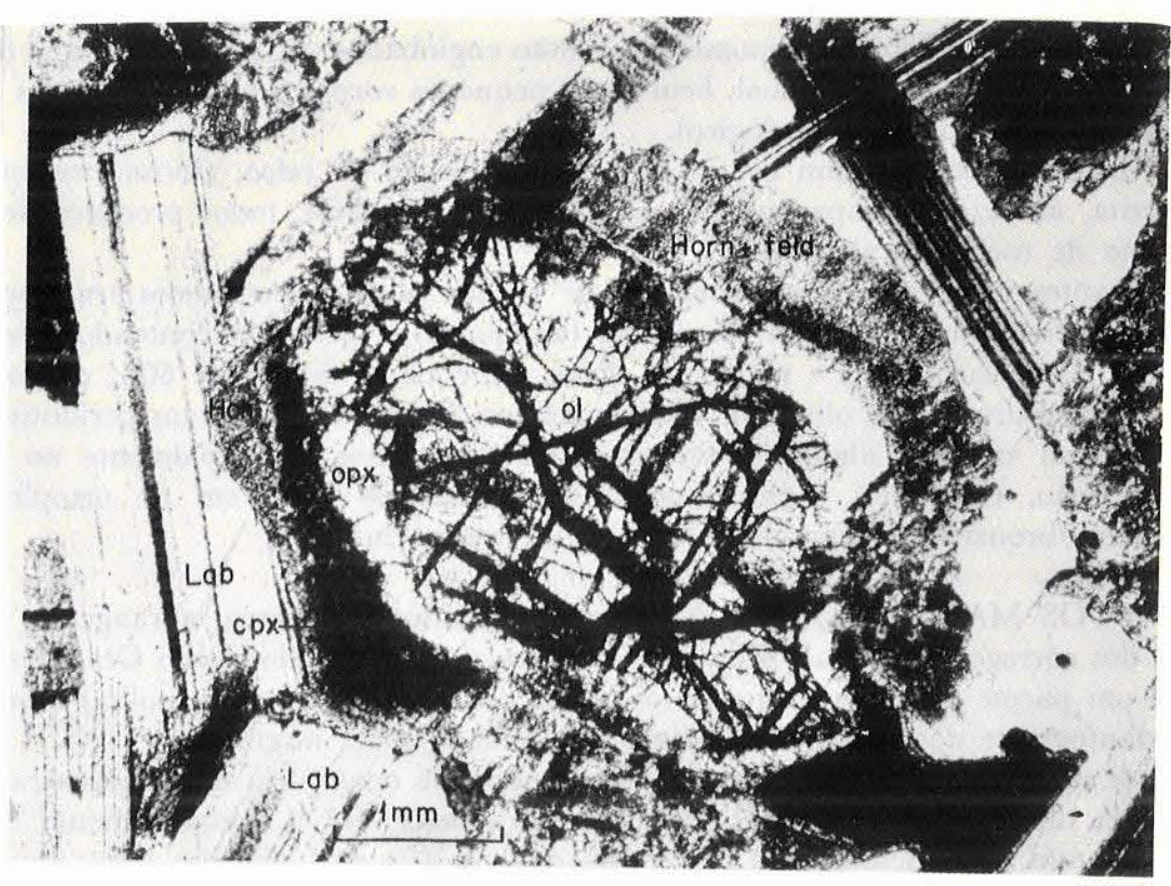

Fotomicrografia 3 - Troctolito com olivina envolvida por uma coroa reacional tripla (hiperstênio, clinopiroxênio e hornblenda) formada através da reação olivina + labradorita. LP, 25 X

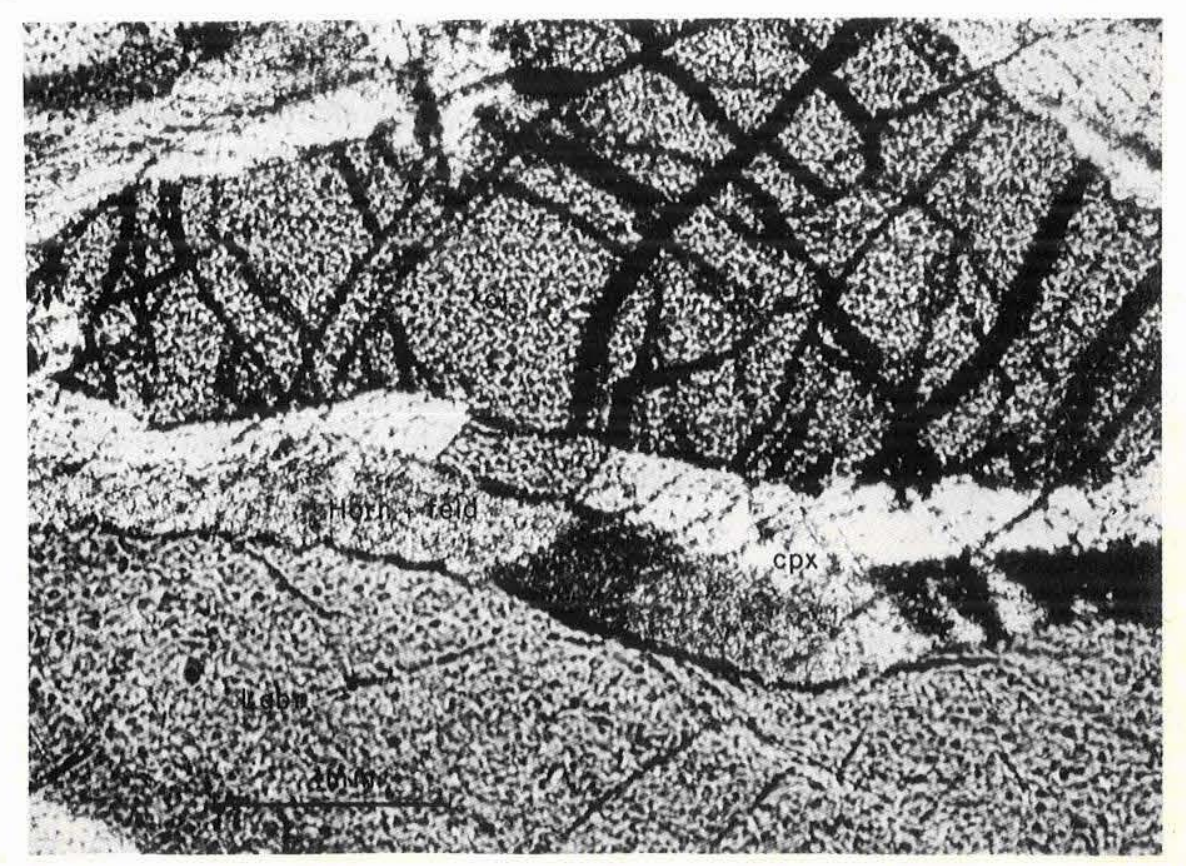

Fotomicrografia 4 - Detalhe de uma coroa de reação dupla envolvendo a olivina. Composta de clinopiroxênio e simplectitos de hornblenda verde-pálido e feldspato. Externamente plagioclásio fissurado. LP, $40 \mathrm{X}$ 
Rochas ultrabásicas Sob essa denominação, estão englobadas várias litologias que formam o núcleo do maciço do Mangabal, bem como pequenos corpos intrusivos, isolados no seio dos gnaisses (veja o mapa geológico).

A litologia mais comum consta de uma associação de talco, clorita, serpentinas e magnetita, às vezes acompanhada de carbonatos e antofilita, todos produtos de transformação de rocha ultrabásica.

Bastantes raros são os afloramentos de rochas ultrabásicas menos transformadas. Nestes, apresentam-se ricas em serpentina (antigorita) e tremolita contendo subordinadamente talco, carbonatos e magnetita. Esses minerais perfazem até $60 \%$ da rocha. O restante é constituído de olivina e clinopiroxênios. Originalmente eram peridotitos.

Ocorrem também alguns afloramentos de piroxenitos, principalmente no maciço de São João, compostos exclusivamente de cristais de até $1 \mathrm{~cm}$ de ortopiroxênios (hiperstênio/bronzita) e diopsídio. Trata-se de websteritos.

OS XISTOS MAGNESPANOS Na porção setentrional da área, abrangendo as nascentes dos córregos Taquaral, Morador, Taquaralzinho e dos rios Indio Grande e Forte, ocorre um pacote de xistos magnesianos (talco, clorita, antigorita, tremolita) sobrepostos discordantemente aos muscovita gnaisses e biotita gnaisses migmáticos.

Três importantes feições caracterizam o modo de ocorrência destes xistos, a saber: (a) ampla distribuição horizontal, crescente para oeste; (b) o comportamento regional sub-horizontal, evidenciado pela ocorrência dos gnaisses ao longo das drenagens, e dos xistos nas encostas e altos topográficos; (c) a existência de núcleos de serpentinitos com olivina e piroxênio residuais.

São rochas de cores esverdeadas, estrutura maciça, tato untuoso proeminente. Quando ricos em serpentina, apresentam maior resistência e cor verde-escura. A xistosidade é dificilmente perceptível.

A rocha-tipo consiste de um talco-clorita xisto em que a clorita e o talco se associam em porcentagens variáveis, gradando para talco xistos, talcitos ou clorititos.

Microscopicamente, é característica a paragênese formada por talco, clorita incolor ou levemente esverdeada, tremolita-actinolita, apoiada sobre um fundo de antigorita e arranjado segundo a textura diablástica. Associam-se ainda carbonatos (magnesita), quer disseminadamente ou em romboedros, a magnetita e epídoto (Fotomicrografia 5).

OS METASSEDIMENTOS DA SERRA DOURADA Turmalina-clorita xistos Ocorre concordantemente sotoposta aos quartzitos da Serra Dourada uma camada descontínua de turmalina-clorita xisto com espessura máxima de $5 \mathrm{~m}$. No microscópio, identificam-se a clorita, muscovita, quartzo, minerais opacos e abundantes prismas de turmalina verde (Fotomicrografia 6).

Quartzitos A Serra Dourada é sustentada por um pacote de quartzitos muscovíticos com cerca de $40 \mathrm{~m}$ de espessura que se distribui segundo a direção geral leste-oeste ao longo da porção meio-norte da área mapeada, com mergulhos de 5 a $20^{\circ}$ para sul.

Inúmeras falhas transversas de direções próximas do norte-sul abateram ou deslocaram partes do pacote quartzítico. Estes se caracterizam por uma sucessão de bancos métricos ou decimétricos (5 a $0,2 \mathrm{~m}$ ) superpostos em estratificações planoparalelas. A granulação é média, às vezes fina quando podem ser friáveis. As estruturas primárias constam de marcas ondulares e estratos cruzados.

Nas proximidades de falhas ou fraturas são freqüentes os estratos silicificados e veios de quartzo leitoso. 


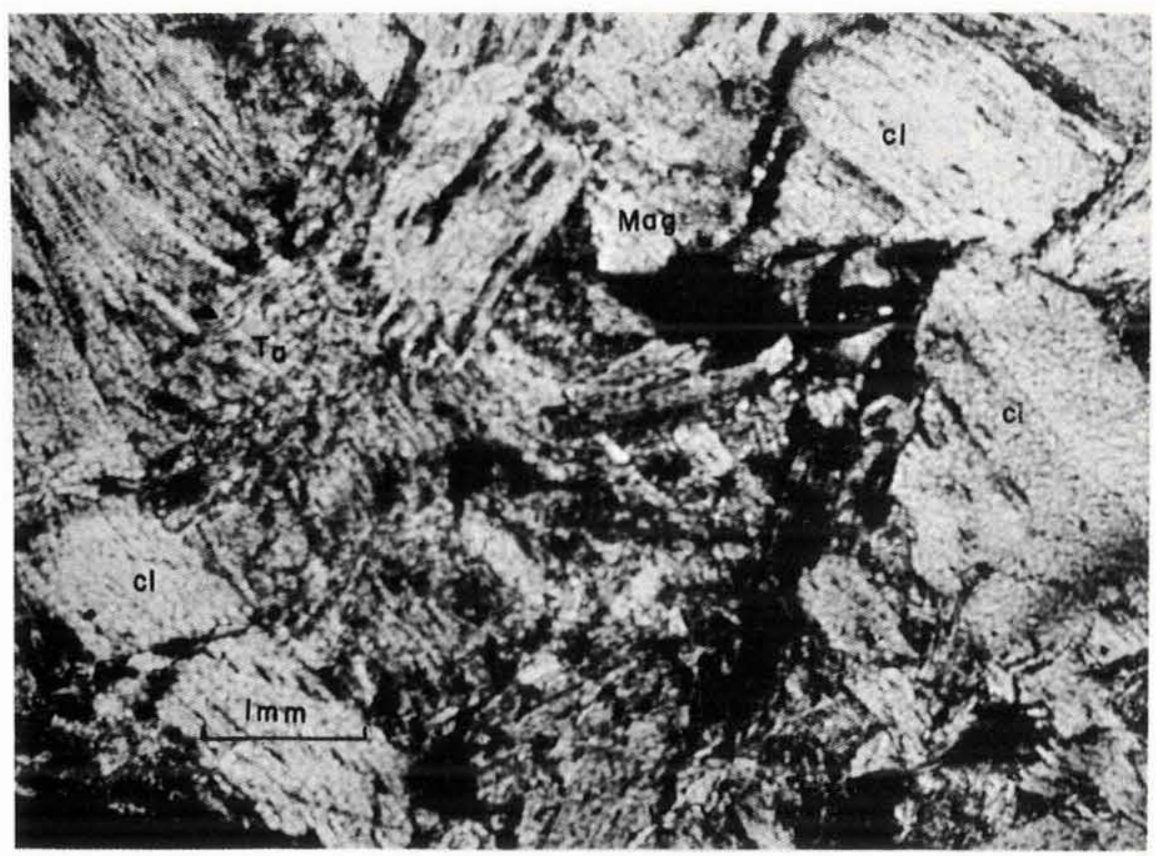

Fotomicrografia 5 - Talco-clorita xisto. A clorita apresenta-se em lamelas bem desenvolvidas sobre o fundo composto de talco e magnetita. LP, $25 \mathrm{X}$

Posto que apresentem intenso fraturamento, fácil desagragação em placas e atitude sub-horizontal, nos altos da serra, a erosão desenvolveu campos de pedras pedestais, conferindo à região uma paisagem ruiniforme (Foto 1).

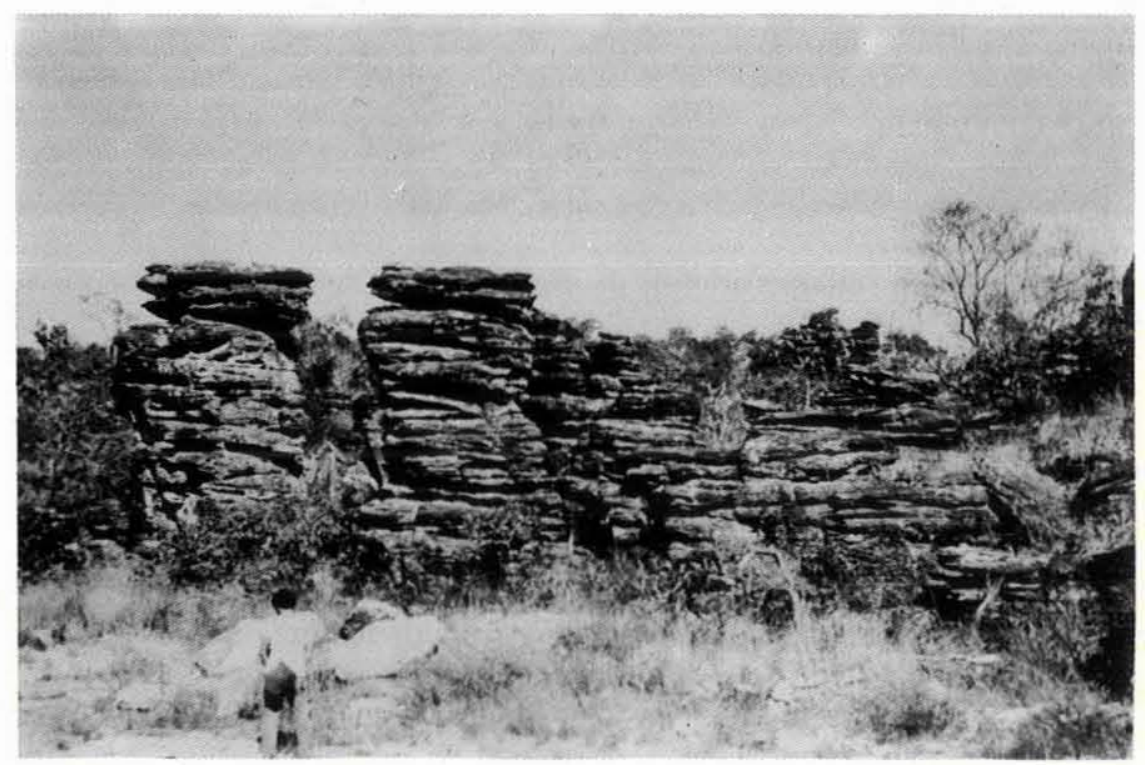

Foto 1 - Quartzitos muscovíticos sub-horizontais do topo da Serra Dourada. Estrada da Pedra Goiana 
Conglomerados intraformacionais No topo dos quartzitos da Serra Dourada, ocorrem lentes de conglomerados intraformacionais com espessuras de até $15 \mathrm{~m}$ e centenas de metros de extensão. Os seus seixos são compostos de quartzito com diametros médios entre $10 \mathrm{e}$ $15 \mathrm{~cm}$. A ocorrência de seixos de quartzo leitoso ou sacaróide e quartzito hematítico é localmente abundante. Em algumas lentes, os seixos encontram-se perfeitamente arredondados e com superfícies lisas. Em outras, estão estirados segundo a xistosidade e apresentam formas elipsoidais achatadas. São grosseiramente acamados e a estratificação só é visível através das raras intercalações quartzíticas. A matriz é arenosa grossa e muscovítica (Fotos 2 e 3).

Das eluviões e coluviões derivadas desses conglomerados vem sendo explorado o diamante.

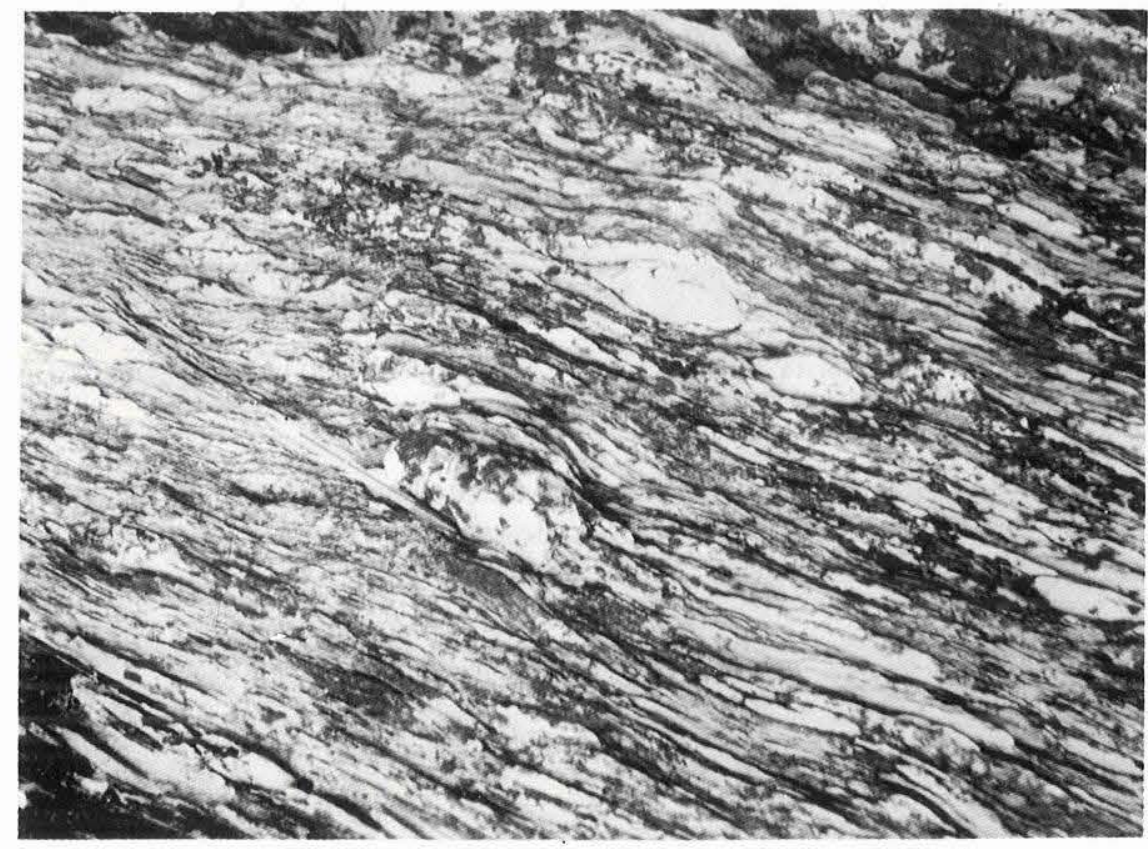

Foto 2 - Conglomerados intraformacionais da Serra Dourada apresentando os seixos achatados e estirados

Quartzo xistos e filitos Sobreposta aos quartzitos da Serra Dourada, ocorre uma seqüência dominantemente composta de quartzo xistos contendo intercalações métricas de quartzitos muscovíticos laminados ou maciços. Em direção a topo, tornam-se comuns camadas de filitos sericíticos e cloritosos, por vezes turmaliníferos, finamente xistosos e com brilho prateado. Camadas de filitos grafitosos são também encontradas.

Essa seqüência apresenta uma persistente continuidade lateral, apesar de se acunhar em direção ao oeste da área. A sua espessura é estimada em cerca de $250 \mathrm{~m}$.

Os quartzo xistos apresentam uma xistosidade muito regular, marcada por níveis milimétricos de quartzo e muscovita. A passagem para os filitos se faz pela diminuição do quartzo e correlativo aumento da sericita. Grânulos feldspáticos não geminados (albita?) e de minerais opacos são comuns (Foto 4). 


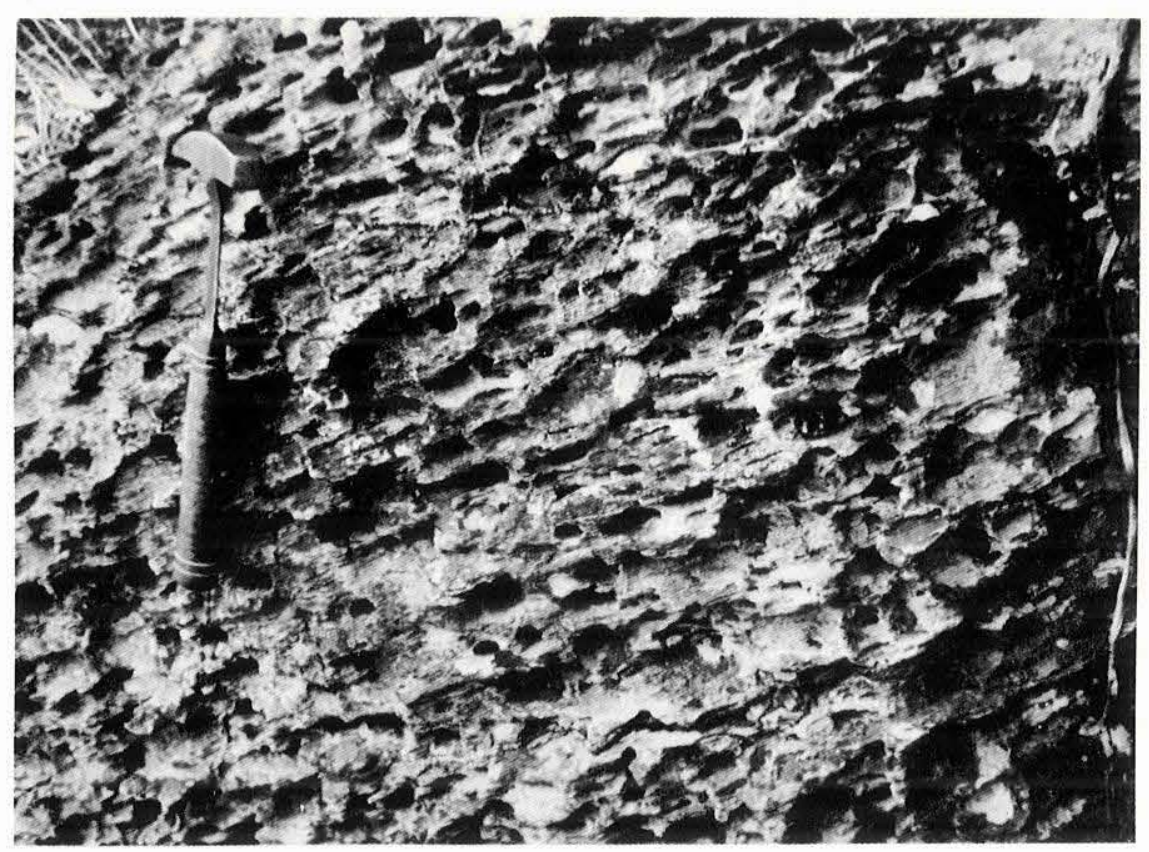

Foto 3 - Conglomerados intraformacionais. A foto mostra os moldes dos seixos retirados pela erosão

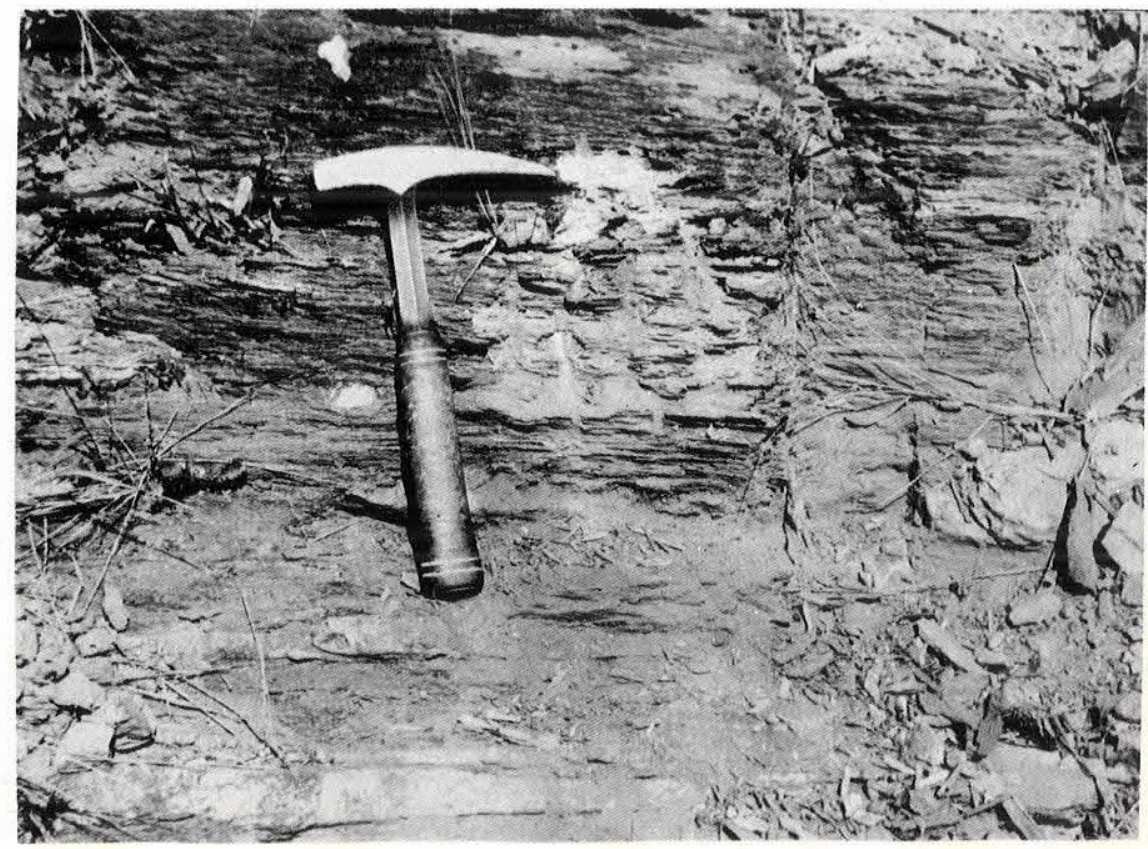

Foto 4 - Quartzo xisto com intercalações centimétricas de quartzitos e seccionados por fraturas verticais 


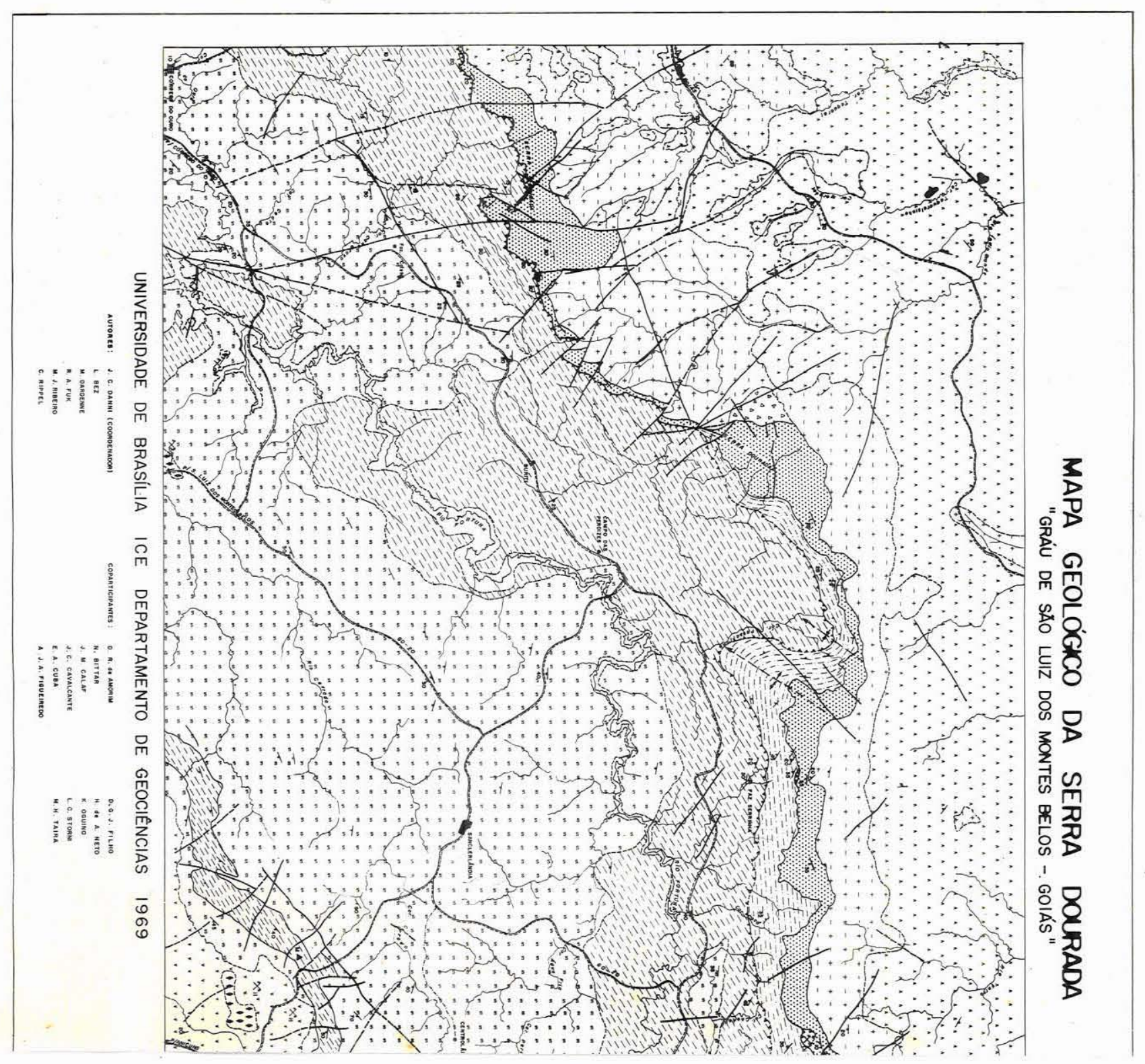




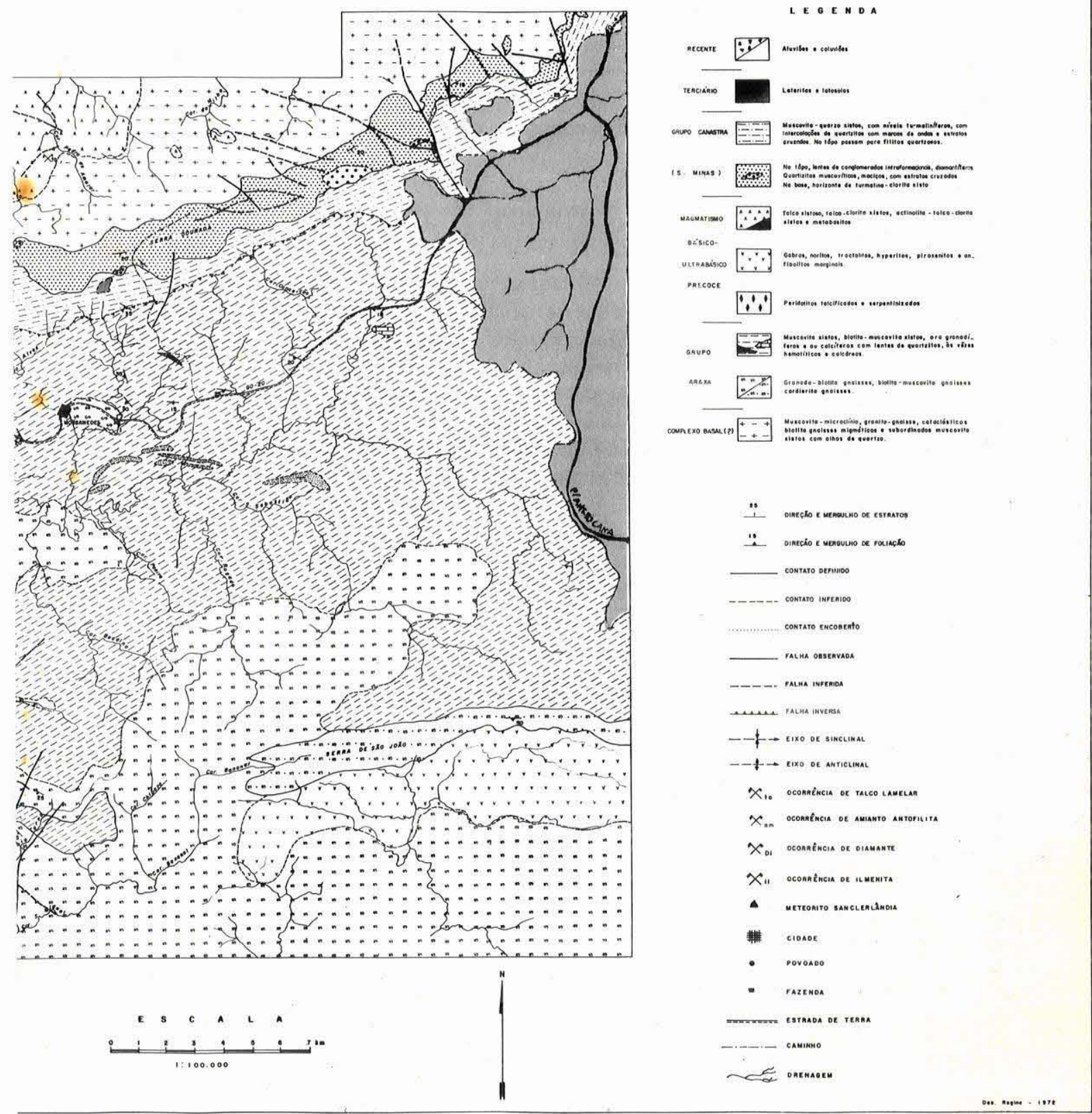


LATERITAS E LATOSSOLOS Na parte sudeste da área a uma altitude geral de 500-550 m desenvolve-se uma extensa região de lateritas concrecionais e solos vermelhos do tipo latossolo instalados sobre biotita xistos e biotita-muscovita gnaisses.

Um único e pequeno testemunho laterítico, a aproximadamente $800 \mathrm{~m}$, ocorre nos altos da Serra Dourada, a $1 \mathrm{~km}$ a oeste da estrada da Pedra Goiana.

ALUVIÕES E COLUVIÕES As aluviões encontram-se bem desenvolvidas no Rio Fartura e, localmente, nos tributários maiores, como o Ribeirão Conceição. Constam basicamente de areias contendo seixos e blocos principalmente de quartzitos e xistos. No sopé da Serra Dourada são comuns depósitos coluviais, compostos de fragmentos e blocos de quartzitos.

TECTONICA E METAMORFISMO As principais feições estruturais observadas na área compreendem:

a) a existência de uma discordância estrutural (angular) e metamórfica entre os granito gnaisses muscovíticos e os quartzitos da Serra Dourada. A continuação do mapeamento para regiões ao norte da cidade de Goiás revelou a existência de um conglomerado com seixos de gnaisses na base dos quartzitos;

b) a distribuição dos metassedimentos da Serra Dourada segundo a direção geral leste-oeste, sotopostos a um falhamento de inversão segundo a mesma direção;

c) a ocorrência em todas unidades estratigráficas de eixos de dobras e de xistosidade secundária (slip-strain cleavage) com coordenadas N50-70W, obliquamente superpostas às estruturas precedentes;

d) a ocorrência de uma tectônica de blocos, caracterizada pelo desenvolvimento de falhas direcionais nordeste e noroeste, transversas às estruturas mencionadas. Acompanha-a um intenso fraturamento, especialmente evidente nos quartzitos.

Em alguns blocos falhados, observa-se o deslizamento na base dos quartzitos sobre gnaisses do norte. Preenchendo fraturas e falhas são extremamente comuns veios de quartzo leitoso. A partir desses fatos e da estratigrafia adotada, impõe-se considerar a existência de, no mínimo, dois ciclos tectônicos, que, no total, abrangem três fases de dobramento.

O primeiro ciclo, cujos traços estruturais foram apagados pelo ciclo posterior, corresponde à primeira fase de dobramentos e metamorfismos dos mica xistos e gnaisses do sul.

As paragêneses encontradas nessas rochas permitem agrupá-las nas fácies almandina anfibolito (zonas da estaurolita e cianita) e xistos verdes altos (zona da biotita-almandina).

Visto não conhecermos as relações estratigráficas entre os gnaisses e mica xistos do sul e os granito-gnaisses do norte da área, incluímos essas rochas num mesmo ciclo. No entanto é muito provável que os gnaisses do norte pertençam a um ciclo mais antigo, relacionado ao Complexo Basal Goiano (Almeida, 1967 e Hasuy e Almeida, 1970).

A primeira fase do segundo ciclo encontra-se representado pelas direções das camadas da Serra Dourada (leste-oeste) que caem em flanco normal para sul com mergulhos de 5-20 . Moldando-se a essa direção e cavalgando os metassedimentos da Serra Dourada, ocorre uma falha inversa, que evidencia o sentido dos esforços de sul para norte.

O metamorfismo gerou paragêneses típicas dos xistos verdes da zona da clorita. A essa etapa metamórfica devem corresponder as feições de instabilidade parágenéticas (cloritizações, sericitizações, epidotizações, etc.) observadas nos gnaisses e mica xistos mais antigos.

A segunda fase desse ciclo corresponde a uma mudança de pólos dos esforços. Encontra-se materializada através dos eixos de redobramentos e de xistosidades secun- 
dárias de direções N50-70W. Esses elementos estruturais seccionam todas as estruturas precedentes. Por serem os mais jovens, são os mais conspícuos na área. A vergência dos dobramentos é para nor-nordeste.

As generalizadas feições da cataclase, deformações e rotações de minerais e a presença marcante de uma xistosidade secundária são os exemplos das últimas adaptações texturais e estruturais aos dobramentos.

OCORRÊNCIAS MINERAIS Ilmenita-magnetita Foram observadas duas ocorrências de ilmenita e magnetita, ambas intercaladas nos gabros do maciço do Mangabal. Os afloramentos são restritos, tendo o maior deles $5 \times 10 \mathrm{~m}$.

Amianto Correspondem a ocorrências de fibras de antofilita restritas a pequenos corpos ultrabásicos completamente serpentinizados e antofilitizados (veja o mapa geológico). A antofilita aparece em veios centimétricos ou em bolsões na rocha ultrabásica transformada.

Talco Associados aos xistos magnesianos do norte da Serra Dourada, ocorrem algumas concentrações irregulares de talco, que são rudimentarmente exploradas. Trata-se de afloramentos isolados no seio dos talco-clorita xistos, tendo o maior deles cerca de $10 \mathrm{~m}$ de diâmetro. $\mathrm{O}$ talco apresenta-se lamelar bastante puro, ou associado à tremolita e magnetita disseminadas.

Diamante À meia-encosta do flanco sul da Serra Dourada, a noroeste de Mossâmedes, ocorrem depósitos aluviais e coluviais provenientes da desagregação das lentes de conglomerados e que vêm sendo garimpados para diamante. O maior diamante encontrado possuía cerca de 15 quilates. Apesar disso, raras são as pedras com mais de 1 quilate, sendo que a produção atinge alguns décimos de quilate por metro cúbico de cascalho lavado.

Essa ocorrência permite considerar as demais lentes de conglomerados assinaladas no mapa e os colúvios relacionados como potencialmente diamantíferas. Nesse sentido, deve-se assinalar a ocorrência, a alguns quilômetros a juzante, das aluviões do Rio Fartura.

Meteorito Sanclerlândia Foi encontrado por M. J. Ribeiro, em outubro de 1971, no cume da Serra do Mangabal, um meteorito de $278 \mathrm{~kg}$, denominado de Sanclerlândia. Trata-se de um siderito que possui $7,33 \%$ de $\mathrm{Ni}$ (octaedrito médio) e que apresenta inclusões microscópicas de troilita e laurencita $\left(\mathrm{FeCl}_{2}\right)$.

\section{BIBLIOGRAFIA}

ALMEIDA, F. F. M. - 1940 - Contribuição à geologia dos Estados de Goiás e Mato Grosso. Div. Geol. Miner., Not. Prel. Est., 46. Rio de Janeiro

ALMEIDA, F. F. M. - 1948 - Reconhecimento geomórfico nos Planaltos divisores das Bacias Amazônicas e do Prata entre os meridianos $51^{\circ}$ e $56^{\circ}$ W. G. Rev. Bras. Geografia, ano X, (3). Rio de Janeiro

ALMEIDA, F. F. M. - 1967 - Observações sobre o Pré-Cambriano da região central de Goiás. Bol. Par. Geoc., 26: 19-22. Curitiba

CASTER, K. E. - 1947 - Expedição geológica em Goiás e Mato Grosso. Min. e Met., 12 (69). Rio de Janeiro

BARBOSA, O. - 1955 - Guia das Excursões ao IX Congresso Brasileiro de Geologia, Not. n. ${ }^{\circ} 3$, S. B. G. São Paulo

BARBOSA, O., BRAUN, O. P. G., DYER, R. C. e CUNHA, C. A. B. R. - 1970 - Geologia da Região do Triângulo Mineiro. Bol. n. ${ }^{\circ}$ 136, DFPM-DNPM, Min. Min. Energia. Rio de Janeiro 
ERIGHSEN, A. F. e LOEFGREEN, A. - 1940 - Geologia de Goiás a Cuiabá. D. F. P. M., Bol. 102. Rio de Janeiro

ERIGHSEN, A. F. e MIRANDA, J. - 1939 - Geologia do Sul de Goiás D. N. P. M. Serv. Geol. e Miner., Bol. n. ${ }^{\circ}$ 94. Rio de Janeiro

FIGUEIREDO, A. N., NILSON, A. A., MOTTA, J., BAETA, J. D. A., ROSITO, J. e ARAÚJO, V. A. - 1970 - Excursão geológica a Barro Alto e Niquelância. XXIV Congr. Bras. Geol., Bol. Esp. n. ${ }^{\circ}$ 2, pp. 11-37

HASUY, Y. e ALMEIDA, F. F. M. - 1970 - Geocronologia do Gentro-Oeste Brasileiro. Bol. Soc. Bras. Geol., 19 (1): 5-26

LEINZ, V. e LEONARDOS, O. H. - 1936 - Notas sobre as Esmeraldas da Fazenda das Lages, Itaberaí, Goiás. DNPM-SFPM, Avulso n. ${ }^{\circ} 13$

LEONARDOS, O. H. - 1938 - Rutilo em Goiás. DNPM-SFPM, Bol. n. ${ }^{\circ}$ 30, Rio de Janeiro

LINDENMAYER, Z. G. e LINDENMAYER, D. H. - 1971 - Caracterização petrográfica das rochas ultramáficas do Complexo do Tocantins, Goiás - XXV Congr. Bras. Geol., Bol. Esp. n. ${ }^{\circ} 1$, pp. 33

MILEWSKI, J. P., PAMPLONA, R., OSTRONOFF, C. e SARMENTO, G. E. M. - 1970 Excursão geológica à Região de Canabrava. XXIV Congr. Bras. Geol., Bol. Esp. n. ${ }^{\circ}$ 2, pp. $115-130$

OLIVEIRA, A. I. e LEONARDOS, O. H. - 1943 - Geologia do Brasil. Min. Agric., Série Didática, n. $^{\circ} 2,2 .^{a}$ ed.

PECORA, W. I. e BARBOSA, A. L. M. - 1944 - Nickel Silicate and associated Cobalt-Manganese oxide deposits near São José do Tocantins, Goyas, Brazil. USGS, Bull. 935-E

RAMOS, J. R.A. - 1958 - Reconhecimento Geológico da Serra Dourada. in Relat. Anual. do Diretor, ano 1958, Div. Geol. Miner., DNPM, pp. 70-72

TEIXEIRA, D. - 1960 - Relevo de "cuestas" em rochas metamórficas da Série Minas, Estado de Goiás. Bol. Soc. Bras. Geol., 9 (1): 43-46

WINKLER, H. G. F. - 1970 - Petrogenesis of metamorphic rocks, New York, Springer-Verlag, $2{ }^{a}$ ed., 237 p. 